\title{
KARAKTERISTIK FISIKOKIMIA DAN MIKROBIOLOGI MODIFIED CASSAVA FLOUR (MOCAF) YANG DIFERMENTASI MENGGUNAKAN STARTER KERING
}

\section{THE PHYSICOCHEMICAL AND MICROBIOLOGICAL CHARACTERISTICS OF FERMENTED MODIFIED CASSA VA FLOUR (MOCAF) BY USING THE DRY STARTER}

\author{
Yuniar Khasanah ${ }^{1}$, Rifa Nurhayati $^{1}$, Ardhea Mustikasari ${ }^{2}$, Isnaini Werdi Astuti ${ }^{2}$ \\ ${ }^{1}$ Balai Penelitian Teknologi Bahan Alam - Lembaga Ilmu Pengetahuan Indonesia \\ ${ }^{2}$ Fakultas Pertanian, Universitas Sebelas maret \\ Jalan Yogya-Wonosari km 31,5 Gading, Playen, Gunungkidul, Yogyakarta, Indonesia. \\ Telp. +62 0274-392570 \\ Email : yuniar.khasanah@lipi.go.id; yuniar.khasanah@gmail.com
}

Diterima : 02-12-2020

Revisi : 16-01-2021

Disetujui : 14-06-2021

\begin{abstract}
ABSTRAK
Perbaikan proses mocaf di UMKM penting dilakukan agar menghasilkan mocaf yang berkualitas. Penelitian ini dilakukan untuk mengetahui pengaruh varietas ubi kayu (Gambyong, Kuning, Ketan, Boyem, dan Gatotkaca), jenis fermentasi (spontan (O), penambahan starter kering "Starmof" (S)), serta kombinasi keduanya terhadap karakteristik fisik, kimia, dan mikrobiologi mocaf. Rancangan yang digunakan adalah Rancangan Acak Lengkap Faktorial (RALF) dua faktor dan analisis data menggunakan SPSS two-way ANOVA, dilanjutkan dengan uji beda nyata Duncan Multiple Range Test (DMRT, a : 95\%). Hasil menunjukkan bahwa varietas ubi kayu berpengaruh nyata terhadap derajat putih; kadar air; abu, protein, lemak dan karbohidrat. Jenis fermentasi berpengaruh nyata terhadap derajat putih, kadar air, abu, protein. Kombinasi antara varietas dan jenis fermentasi berpengaruh nyata terhadap derajat putih, kadar air, abu, protein, lemak dan karbohidrat. Fermentasi dengan penambahan starter memiliki suhu gelatinisasi dan viskositas balik lebih tinggi serta viskositas puncak dan dingin lebih rendah. Derajat putih mocaf 89,60-90,86\% (SNI minimal 87\%); kadar air 5,15-6,92\% wb (SNI maksimal $13 \% \mathrm{wb}$ ), abu $0,20 \%-0,46 \% \mathrm{db}$ atau setara dengan 0,18\%-0,43\% wb (SNI maksimal $1,5 \% \mathrm{wb}$ ), protein $0,78 \%-1,21 \%$, lemak $0,37 \%-0,62 \%$, angka lempeng total $3,6 \times 10^{2}-$ $2,7 \times 10^{3} \mathrm{koloni} / \mathrm{g}$ (SNI maksimal $1 \times 10^{6} \mathrm{Koloni} / \mathrm{g}$ ), angka kapang/khamir $<2,5 \times 10^{2}-7,6 \times 10^{2} \mathrm{Koloni} / \mathrm{g}$ (SNI maksimal $1 \times 10^{4}$ Koloni/g).
\end{abstract}

Kata kunci: fermentasi, mocaf, starter kering, ubi kayu, varietas

\section{ABSTRACT}

It is important to improve mocaf processing at the SME to produce mocaf with good quality. This study was aimed to determine the physicochemical and microbiological characteristics of mocaf from cassava (Gambyong, Kuning, Ketan, Boyem, and Gatotkaca varieties), fermentation (spontaneous and using dry starter "Starmof"), and the combinations of those. The research using Completely Randomized Design (CRD) and SPSS two-way. The results showed that varieties had a significant effect on whiteness, moisture ash, protein, fat, and carbohydrate. Type of fermentation had a significant effect on whiteness, moisture, ash, protein. The combination between varieties and fermentation had a significant effect on whiteness, moisture, ash, protein, fat, and carbohydrate. Fermentation using dry starter "Starmof" results higher gelatinization temperature, setback viscosity, lower peak, and final viscosity. The whiteness is 89,60-90,86\% (SNI, minimum 87\%); the moisture is 5,15-6,92\% wb (SNI, maximum 13\% wb), ash is 0,20\%-0,46\% db or equivalent with $18 \%-0,43 \%$ wb (SNI, maximum 1,5\% wb), protein is $0,78 \%-1,21 \%$, fat is $0,37 \%-0,62 \%$, total plate count 3,6x102$2,7 \times 103$ coloni/g (SNI, maximum $1 \times 10^{6}$ coloni/g), kapang/khamir $<2,5 \times 10^{2}-7,6 \times 10^{2}$ coloni/g (SNI, maximum $1 \times 10^{4}$ coloni/g). 


\section{PENDAHULUAN}

bi kayu (Manihot esculenta Crantz) merupakan sumber karbohidrat yang menduduki urutan kedua terbesar di Indonesia setelah beras. Selain digunakan sebagai sumber karbohidrat, ubi kayu juga dimanfaatkan sebagai bahan baku industri serta pakan ternak (Khasanah, Y. dan Helmi, 2020). Upaya diversifikasi pangan sumber karbohidrat non beras meningkatkan konsumsi ubi kayu sebagai sumber karbohidrat menjadi 10,5 kg/kapita/tahun atau mengalami peningkatan sebesar 1,9 kg/kapita/tahun. Peningkatan ini memberikan kontribusi konsumsi karbohidrat sebesar $40 \%$. Target konsumsi ubi kayu diprediksikan menjadi 18,1 kg/kapita/tahun pada tahun 2024 melalui program diversifikasi ini (Hendriadi, 2020).

Gunungkidul merupakan wilayah yang sebagian daerahnya memiliki tanah yang tandus, terjal, kering, dan hanya memperoleh air dari tangkapan air hujan, tanaman ubi kayu mampu tumbuh dengan baik di daerah ini (Sarjiyah, et al, 2016). Menurut Badan Pusat Statistik (2015), luas panen tanaman singkong di Gunungkidul tahun 2015 mencapai 50.415 Ha (luas total di DIY 55.628 Ha). Menurut Badan Ketahanan Pangan dan Penyuluhan DIY (2016), tingkat produksi ubi kayu di Kabupaten Gunungkidul 781.609 ton dari produksi total ubi kayu di DIY 873.362 ton pada tahun 2015.

Ubi kayu segar mempunyai umur simpan yang tidak lama yaitu 2-5 hari setelah pemanenan (Sagala dan Suwarto, 2017) dan harga jualnya yang sangat murah. Pada saat musim panen, harga ubi kayu lebih murah, yaitu Rp. 500 - Rp. 800 per kg. Sedangkan di luar musim panen harga di tingkat petani Rp. 900 - Rp. 1.100 (Kementerian Perdagangan RI, 2016). Oleh karena itu, pengolahan ubi kayu sangat diperlukan untuk memperpanjang umur simpan dan meningkatkan nilai jualnya. Mocaf (modified cassava flour) merupakan produk tepung dari ubi kayu yang prosesnya melalui modifikasi sel ubi kayu secara fermentasi (Subagio, 2013). Fermentasi mocaf secara spontan mempunyai kelemahan, yaitu waktu fermentasi yang lama dan kualitas hasil fermentasi yang kurang seragam (Kurniadi, et al, 2014), mikroba yang tumbuh sedikit sehingga mutu produk yang dihasilkan memiliki kualitas rendah (Wulandari et al, 2021).

Badan Keswadayaan Masyarakat (BKM) di Desa Semugih, Kecamatan Rongkop memiliki beberapa kegiatan, salah satu diantaranya melakukan proses pembuatan mocaf. Ubi kayu yang digunakan dalam pembuatan mocaf yaitu ubi kayu varietas lokal yang dibudidayakan oleh petani di wilayah tersebut. Varietas yang sering digunakan yaitu: varietas gambyong, kuning, ketan, boyem dan gatotkaca. Poses pembuatan mocaf selama ini menggunakan teknik fermentasi spontan, sehingga dibutuhkan waktu proses yang lebih lama dan kualitas tepung mocaf yang dihasilkan kurang seragam. Kondisi ini mendorong Balai Penelitian Teknologi Bahan Alam Lembaga Ilmu Pengetahuan Indonesia (BPTBA LIPI) untuk mengimplementasikan starter mocaf (Starmof) bentuk kering (bubuk) dalam pembuatan mocaf. Stater ini dalam komposisinya mengandung bakteri Lactobacillus plantarum dan bahan lain sebagai bahan pengisinya. Penambahan Starmof berfungsi memperbaiki kualitas produk mocaf serta mempercepat waktu fermentasi. Penelitian ini dilakukan untuk mengkaji proses pembuatan mocaf yang dilakukan oleh BKM dengan menggunakan berbagai varietas ubi kayu serta proses fermentasi yang dilakukan (fermentasi spontan dan fermentasi dengan penambahan starter) terhadap karakteristik fisik, kimia, dan mikrobiologinya. 


\section{METODE PENELITIAN}

\section{Waktu dan tempat penelitian}

Penelitian ini dilaksanakan di Laboratorium Kimia dan Laboratorium Mikrobiologi Balai Penelitian Teknologi Bahan Alam Lembaga Ilmu Pengetahuan Indonesia Gunungkidul Yogyakarta, Laboratorium Uji Proksimat Balai Besar Tanaman Padi Subang, dan Laboratorium Pangan dan Gizi Fakultas Teknologi Hasil Pertanian Universitas Gadjah Mada Yogyakarta. Waktu penelitian dilaksanakan pada bulan Agustus 2017 sampai Juni 2018.

\section{Bahan dan alat}

Bahan utama yang digunakan dalam penelitian, yaitu: ubi kayu (varietas gambyong, kuning, ketan, boyem dan gatotkaca) yang diperoleh dari petani Desa Semugih, Kecamatan Rongkop, Gunungkidul, stater kering (starmof) dari BPTBA LIPI. Bahan untuk analisis antara lain aquades, $\mathrm{NaOH}$ (Merck) 0,1 N, pikrat basa (pH 11), $\mathrm{KCN}$ (Merck), $\mathrm{CuSO}_{4}$ (Merck), $\mathrm{K}_{2} \mathrm{SO}_{4}$ (Merck), $\mathrm{H}_{2} \mathrm{SO}_{4}$ (Sigma), $\mathrm{NaOH}$ (Merck), $\mathrm{H}_{3} \mathrm{BO}_{3}$ (Sigma), indikator $\mathrm{BCR}+\mathrm{MR}$, larutan standar $\mathrm{HCl}$, petrolium eter (Merck), PCA (Oxoid), PDA (Oxoid), dan kloramfenikol.

Alat yang digunakan dalam penelitian yaitu: pisau stainless, slicer, tray, oven (memmert), Loyang (stainless), blender (Philips), ayakan 80 mesh, timbangan (Camry 505), Color reader (CR-20 Konica Minolta), Rapid Visco Analyzer (DV-II Pro), pH meter (Hanna HI 8424), spektrofotometer (Thermo Scientific Genesys 10S UV-Vis), Mikro Kjeldhl (Buchi), autoclave (Tomy), LAF (Laminar Air Flow), incubator (Binder BD 56) dan colony counter.

\section{Persiapan Starter}

Starmof merupakan starter kering yang berisi Bakteri Lactobacillus plantarum. Sebelum digunakan, starter terlebih dahulu dicampurkan dengan air hangat $\left(37^{\circ} \mathrm{C}\right)$ sampai homogen dan diinkubasi 18 jam pada suhu ruang $\left( \pm 25^{\circ} \mathrm{C}\right)$ dalam kondisi wadah tertutup (Kurniadi, et al., 2014).

\section{Pembuatan Mocaf}

Proses pembuatan mocaf untuk semua varietas dibagi dalam dua cara, yaitu fermentasi spontan (tanpa penambahan starter) dan fermentasi dengan penambahan starter (starmof). Untuk pembuatan mocaf secara spontan, Ubi kayu dikupas hingga bersih dan dipotong melintang tipis (chips) ketebalan $\pm 1 \mathrm{~mm}$. Chips (2 kg) difermentasi dengan cara perendaman dengan perbandingan chips : air 1:2 (b/v). Fermentasi dilakukan selama 72 jam, dan setiap 24 jam sekali dilakukan penggantian air. Setelah 72 jam, dilakukan pencucian chips, pengeringan menggunakan oven (Memmert, suhu $50{ }^{\circ} \mathrm{C}, 24$ jam), penggilingan (blender), pengayaan (80 mesh) dan pengemasan.

Pembuatan Mocaf dengan Penambahan Starmof, setelah fermentasi selama 24 jam (fermentasi tahap 1), kemudian dilakukan penambahan starmof $(0,4 \mathrm{~g} / 20 \mathrm{ml}$ air). Fermentasi dilanjutkan kembali selama 24 jam (fermentasi tahap II). Chips dicuci menggunakan air bersih lalu dikeringkan (oven Memmert, suhu $50{ }^{\circ} \mathrm{C}, 24$ jam), dihaluskan (80 mesh) dan dikemas. Perlakuan dalam pembuatan mocaf adalah sebagai berikut (Tabel 1) 
Tabel 1. Perlakuan proses pembuatan mocaf

\begin{tabular}{lcc}
\multicolumn{1}{c}{ Varietas ubi kayu } & \multicolumn{2}{c}{ Tipe fermentasi } \\
\cline { 2 - 3 } \multicolumn{1}{c}{ Spontan (o) } & Starter (s) \\
\hline Gambyong (Gb) & Gbo & Gbs \\
Kuning (Ku) & Kuo & Kus \\
Ketan (Ke) & Keo & Kes \\
Boyem (By) & Byo & Bys \\
Gatotkaca (Gk) & Gko & Gks \\
\hline
\end{tabular}

\section{Karakterisasi Mocaf}

Karakterisasi fisik meliputi : derajat putih metode color reader (Hadnađev, et al, 2013), amilografi metode Rapid Visco Analyzer (Brookfield Engineering Laboratories, 2005). Karakteristik kimia meliputi: kadar air metode thermogravimetri (AOAC, 2000), kadar abu metode langsung (AOAC, 2000), protein metode Kjeldahl (AOAC, 2000), lemak metode ekstraksi soxhlet (AOAC, 2000), karbohidrat metode by difference (Winarno, 2008). Karakteristik mikrobiologi meliputi: angka lempeng total metode PCA (SNI 3751-2009) (BSN, 2009), angka kapang/khamir metode PDA (SNI 3751-2009) (BSN, 2009).

\section{Analisis Data}

Data dianalisis secara statistik dengan metode Two Way Analysis of Variances (ANOVA). Bila ada perbedaan perlakuan, dilanjutkan dengan uji Duncan Multiple Range Test (DMRT) dengan $a=0,05$.

\section{HASIL DAN PEMBAHASAN Karakteristik fisik Derajat Putih}

Varietas ubi kayu, fermentasi dan kombinasi antara kedua faktor memiliki pengaruh yang signifikan terhadap derajat putih mocaf (sig. 0.00) (Tabel 2).

Tabel 2. Derajat putih mocaf dari berbagai varietas ubi kayu dan tipe fermentasi

\begin{tabular}{|c|c|c|c|}
\hline \multirow{2}{*}{ Varietas } & \multicolumn{2}{|c|}{ Fermentasi } & \multirow{2}{*}{ Rerata } \\
\hline & Spontan (o) & Starmof (s) & \\
\hline Gambyong (Gb) & $90,77 \pm 0,10$ & $90,47 \pm 0,06$ & $90,62^{d} \pm 0,18$ \\
\hline Kuning (Ku) & $90,56 \pm 0,05$ & $89,87 \pm 0,15$ & $90,21^{b} \pm 0,38$ \\
\hline Ketan (Ke) & $90,86 \pm 0,09$ & $90,02 \pm 0,13$ & $90,44^{\mathrm{c}} \pm 0,45$ \\
\hline Boyem (By) & $90,50 \pm 0,29$ & $89,60 \pm 0,22$ & $90,05^{a} \pm 0,53$ \\
\hline Gatotkaca (Gk) & $90,83 \pm 0,15$ & $89,78 \pm 0,06$ & $90,30^{\mathrm{b}} \pm 0,56$ \\
\hline Rerata & $90,70^{\mathrm{B}} \pm 0,21$ & $89,95^{A} \pm 0,33$ & \\
\hline
\end{tabular}

Salah satu faktor yang mempengaruhi nilai derajat putih dari suatu tepung adalah pigmen alami yang terdapat di dalamnya. Pigmen yang terdapat pada ubi kayu adalah karotenoid. Semua varietas ubi kayu kuning mempunyai jumlah karotenoid yang lebih tinggi dibandingkan dengan varietas ubi kayu putih (Eleazu, dan Eleazu, 2012). Pada mocaf hasil fermentasi menggunakan starter memiliki derajat putih yang lebih rendah. Hal ini terjadi karena waktu fermentasi lebih pendek (48 jam) dibandingkan dengan dengan fermentasi spontan (72 jam). Semakin lama waktu fermentasi maka semakin banyak komponen warna 
yang terdegradasi sehingga tepung yang dihasilkan semakin putih. Menurut Putri et al (2018) fermentasi juga mampu menghambat atau menekan laju reaksi pencoklatan (maillard) yang dapat menyebabkan bahan menjadi berwarna kecoklatan dengan cara merombak gula pereduksi menjadi asam-asam organik. Dengan demikian maka fermentasi menghasilkan mocaf dengan derajat putih yang lebih tinggi. Selain itu, diduga jumlah enzim pektinase dan selulase pada fermentasi dengan penambahan Starmof lebih sedikit dibandingan dengan fermentasi spontan sehingga pigmen karotenoid yang terdegradasi pada fermentasi dengan penambahan Starmof lebih. Nilai derajat putih mocaf pada penelitian ini berada pada rentang $89,60-90,86 \%$ dan telah sesuai dengan SNI 7622-2011 (BSN, 2011) minimal 87\%.

\section{Amilografi}

Fermentasi dengan penambahan starter mengakibatkan suhu gelatinisasi dan viskositas balik semakin tinggi serta viskositas puncak dan dingin semakin rendah (Tabel 3).

Tabel 3. Sifat Amilografi Mocaf dari Berbagai Varietas Ubi Kayu dengan Fermentasi Spontan dan Penambahan Starmof

\begin{tabular}{cccccccc}
\hline & \multicolumn{2}{c}{ Gelatinisasi } & \multicolumn{3}{c}{ Set back Viscosity (cP) } & Viscositas & Viscositas \\
\cline { 2 - 5 } & $\begin{array}{l}\text { Suhu } \\
\left({ }^{\circ} \mathrm{C}\right)\end{array}$ & $\begin{array}{c}\text { Waktu } \\
\text { (menit ke }-)\end{array}$ & $\begin{array}{c}\text { Suhu } \\
\left({ }^{\circ} \mathrm{C}\right)\end{array}$ & $\begin{array}{c}\text { Waktu } \\
(\text { menit ke- })\end{array}$ & $\begin{array}{c}\text { Viscositas } \\
(\mathrm{cP})\end{array}$ & $\begin{array}{c}\text { (cP) } \\
\text { balik (cP) }\end{array}$ \\
\hline Gbo & 73,1 & 12 & 83,7 & 15 & 4730 & 3190 & -1540 \\
Gbs & 73,8 & 12 & 84,9 & 15 & 3535 & 2785 & -750 \\
Kuo & 70,4 & 11 & 85,5 & 15 & 3720 & 2580 & -1140 \\
Kus & 71,1 & 12 & 85,1 & 16 & 3130 & 2360 & -770 \\
Keo & 71,4 & 12 & 88,9 & 17 & 3915 & 2865 & -1050 \\
Kes & 71,9 & 12 & 86,6 & 16 & 4495 & 3080 & -1415 \\
Byo & 72,3 & 12 & 86,6 & 16 & 4175 & 3430 & -745 \\
Bys & 75,7 & 13 & 89,6 & 17 & 2340 & 1865 & -475 \\
Gko & 68,6 & 11 & 87,3 & 16 & 4280 & 3065 & -1215 \\
Gks & 71,9 & 11 & 83,4 & 14 & 3215 & 2190 & -1025 \\
\hline
\end{tabular}

Keterangan: Gbo (Gambyong spontan), Gbs (Gambyong Starmof), Kuo (Kuning spontan), Kus (Kuning Starmof), Keo (Ketan spotan), Kes (Ketan Starmof), Byo (Boyem spontan), Bys (Boyem Starmof), Gko (Gatotkaca spontan), Gks (Gatotkaca Starmof)

Kandungan amilosa sangat berperan pada saat proses gelatinisasi, retrogradasi dan lebih menentukan karakteristik pasta pati. Amilosa pada mocaf yang difermentasi dengan penambahan Starmof lebih tinggi dari mocaf yang difermentasi spontan. Kemungkinan masih banyak amilosa pada mocaf yang difermentasi dengan penambahan Starmof yang belum dipecah menjadi gula-gula sederhana oleh enzim a-amilase sehingga mempunyai viskositas yang lebih rendah. Kadar amilosa tinggi akan mempunyai suhu gelatinisasi yang tinggi karena amilosa cenderung membentuk ikatan hidrogen dengan sesamanya (Yulifianti dan Ginting, 2011); menghambat pengembangan granula pati dengan membentuk kompleks dengan lemak yang mengakibatkan suhu gelatinisasi menjadi tinggi (Putri, 2015); mudah mengalami retrogradasi karena viskositas balik tinggi (Kartikasari, et al, 2016).

\section{Karakteristik kimia \\ Kadar air}

Varietas ubi kayu ,fermentasi dan kombinasi antara kedua faktor mempunyai pengaruh yang nyata (sig. 0,00) terhadap kadar air (Tabel 4). Menurut Amanu dan Susanto, (2014), 
kadar air mocaf dipengaruhi oleh varietas ubi kayu yang digunakan sebagai bahan bakunya, karena kadar air ubi kayu segar pada tiap varietas berbeda. Kadar air ubi kayu segar varietas Gambyong lebih tinggi dibandingkan dengan varietas Gatotkaca yaitu sebesar $64,86 \%$ (wb) dan 53,42\% (wb) (Hastutik, et al, 2017), dan varietas Ketan sebesar 62,34\% (Rosyadi, et al, 2014).

Proses fermentasi mengakibatkan peningkatan kadar air mocaf, semakin lama waktu fermentasi maka semakin tinggi kadar air mocaf yang dihasilkan (Aini, 2013). Kadar air mocaf yang diperoleh dari penelitian ini $(5,15-6,92 \% \mathrm{wb})$, senada dengan hasil penelitian (Seveline, 2018), menunjukkan bahwa mocaf yang difermentasi menggunakan Lactobacillus plantarum selama 72 jam dan 48 jam mempunyai kadar air yang berbeda. Semakin lama perendaman, maka air yang diserap dan berikatan matrik akan lebih banyak.

Table 4. Kadar air Mocaf dari berbagai varietas ubi kayu dan tipe fermentasi

\begin{tabular}{|c|c|c|c|}
\hline \multirow[b]{2}{*}{ Varietas } & \multicolumn{2}{|c|}{ Fermentasi } & \multirow{2}{*}{ Rerata (\%wb) } \\
\hline & Spontan (o) & Starmof (s) & \\
\hline Gambyong (Gb) & $6,92 \pm 0,12$ & $6,61 \pm 0,18$ & $6,76^{\mathrm{e}} \pm 0,22$ \\
\hline Kuning (Ku) & $6,38 \pm 0,12$ & $6,66 \pm 0,04$ & $6,52^{d} \pm 0,17$ \\
\hline Ketan (Ke) & $6,53 \pm 0,05$ & $6,18 \pm 0,11$ & $6,36^{\mathrm{c}} \pm 0,20$ \\
\hline Boyem (By) & $5,53 \pm 0,13$ & $5,36 \pm 0,06$ & $5,44^{b} \pm 0,13$ \\
\hline Gatotkaca (Gk) & $5,44 \pm 0,29$ & $5,15 \pm 0,10$ & $5,28^{a} \pm 0,26$ \\
\hline Rerata (\% wb) & $6,16^{\mathrm{B}} \pm 0,61$ & $5,99^{A} \pm 0,65$ & \\
\hline
\end{tabular}

Keterangan: sig. varietas $=0,000$, sig. jenis fermentasi $=0,000$, sig. varietas*jenis fermentasi $=0,000$, R Squared $=0,960$. Notasi huruf kapital dan huruf kecil yang sama pada kolom dan baris yang sama menunjukkan berbeda tidak nyata pada a

Abu $=0,05$

Varietas ubi kayu, jenis fermentasi dan kombinasi antara kedua faktor memiliki pengaruh yang nyata (sig. 0,00) terhadap kadar abu mocaf yang dihasilkan (Tabel 5). Menurut (Yulifianti dan Ginting, 2011), perbedaan kadar abu pada mocaf terjadi karena adanya perbedaan genetik ubi kayu yang digunakan sebagai bahan baku mocaf. Selain itu, fermentasi spontan membutuhkan waktu yang lebih lama sehingga lebih banyak mineral yang larut ke dalam air rendaman dan juga sebagian besar mineral yang terkandung digunakan oleh mikrobia untuk pertumbuhan dan metabolismenya (Moral, et al, 2017).

Tabel 5. Kadar abu mocaf dari berbagai varietas ubi kayu dan tipe fermentasi

\begin{tabular}{|c|c|c|c|}
\hline \multirow{2}{*}{ Varietas } & \multicolumn{2}{|c|}{ Fermentasi } & \multirow{2}{*}{$\begin{array}{l}\text { Rerata } \\
(\% d b)\end{array}$} \\
\hline & Spontan (o) & Starmof (s) & \\
\hline Gambyong (Gb) & $0,39 \pm 0,01$ & $0,37 \pm 0,02$ & $0,38^{\mathrm{c}} \pm 0,02$ \\
\hline Kuning (Ku) & $0,27 \pm 0,01$ & $0,28 \pm 0,02$ & $0,27^{b} \pm 0,02$ \\
\hline Ketan (Ke) & $0,20 \pm 0,02$ & $0,31 \pm 0,01$ & $0,26^{a} \pm 0,06$ \\
\hline Boyem (By) & $0,38 \pm 0,01$ & $0,46 \pm 0,02$ & $0,42^{d} \pm 0,04$ \\
\hline Gatotkaca (Gk) & $0,32 \pm 0,02$ & $0,42 \pm 0,02$ & $0,37^{\mathrm{C}} \pm 0,06$ \\
\hline Average (\%db) & $0,31^{A} \pm 0,07$ & $0,37^{B} \pm 0,07$ & \\
\hline
\end{tabular}

Keterangan: sig. varietas $=0,000$, sig. tipe fermentasi $=0,000$, sig. varietas $*$ tipe fermentasi $=0,000, \mathrm{R}$ Squared $=0,963$. Notasi huruf kapital dan huruf kecil yang sama pada kolom dan baris yang sama menunjukkan berbeda tidak nyata pada $a=0,05$ 


\section{Protein}

Varietas ubi kayu, jenis fermentasi serta kombinasi antara kedua faktor berpengaruh secara nyata (sig. 0,00) terhadap kadar protein mocaf yang dihasilkan (Tabel 6). Kadar protein mocaf yang berbeda-beda disebabkan oleh beberapa faktor, antara lain karena perbedaan varietas dari ubi kayu yang digunakan, kondisi agroekologi, dan waktu fermentasi (Tefera, et al, 2014). Mocaf yang difermentasi dengan penambahan starter kering mempunyai kadar protein yang lebih tinggi, karena adanya pertambahan jumlah mikroorganisme dalam substrat yang juga berperan sebagai single cell protein (SCP) (Wulandari, et al, 2021). Protein sel tunggal merupakan produk biomassa yang mengandung protein tinggi yang berasal dari mikroba. Bakteri, alga, dan yeast merupakan mikroorganisme yang dapat memproduksi protein sel tunggal (Inuhan, et al, 2016).

Tabel 6. Kadar Protein mocaf dari berbagai varietas ubi kayu dan tipe fermentasi

\begin{tabular}{lccc}
\hline \multirow{2}{*}{ Varietas } & \multicolumn{2}{c}{ Fermentasi } & $\begin{array}{c}\text { Rerata } \\
(\% \mathrm{db})\end{array}$ \\
\cline { 2 - 3 } & Spontan(o) & Starmof(s) & $\left(\% 8^{\mathrm{b}} \pm 0,03\right.$ \\
Gambyong (Gb) & $0,86 \pm 0,02$ & $0,89 \pm 0,03$ & $0,80,85^{\mathrm{b}} \pm 0,04$ \\
Kuning (Ku) & $0,88 \pm 0,02$ & $0,82 \pm 0,03$ & $0,85^{\mathrm{a}} \pm 0,05$ \\
Ketan (Ke) & $0,81 \pm 0,05$ & $0,78 \pm 0,04$ & $0,80^{\mathrm{a}} \pm 0,05$ \\
Boyem (By) & $0,97 \pm 0,04$ & $1,21 \pm 0,05$ & $1,09^{\mathrm{d}} \pm 0,13$ \\
Gatotkaca (Gk) & $0,94 \pm 0,06$ & $1,03 \pm 0,03$ & $0,99^{\mathrm{c}} \pm 0,07$ \\
\hline Rerata (\%db) & $0,89^{\mathrm{A}} \pm 0,07$ & $0,95^{\mathrm{B}} \pm 0,16$ & \\
\hline
\end{tabular}

Ketrangan: sig. varietas $=0,000$, sig. jenis fermentasi $=0,000$, sig. varietas*jenis fermentasi $=0,000, \mathrm{R}$ Squared $=0,921$. Notasi huruf kapital dan huruf kecil yang sama pada kolom dan baris yang sama menunjukkan berbeda tidak nyata pada $a=0,05$

\section{Lemak}

Varietas ubi kayu berpengaruh nyata (sig. 0,00) terhadap kadar lemak mocaf yang dihasilkan sedangkan fermentasi tidak berpengaruh nyata terhadap kadar lemak mocaf yang dihasilkan (sig. 0,62). Kombinasi antara varietas dan fermentasi berpengaruh yang nyata (sig. 0,00) terhadap kadar lemak mocaf yang dihasilkan (Tabel 7).

Tabel 7. Kandungan Lemak Mocaf dari berbagai varietas ubi kayu dan tipe fermentasi

\begin{tabular}{cccc}
\hline \multirow{2}{*}{ Varietas } & \multicolumn{2}{c}{ Fermentasi } & $\begin{array}{c}\text { Rerata } \\
(\% d b)\end{array}$ \\
\cline { 2 - 3 } & Spontan $(0)$ & Starmof $(\mathrm{s})$ & $0,51^{\mathrm{c}} \pm 0,09$ \\
\hline Gambyong (Gb) & $0,59 \pm 0,05$ & $0,43 \pm 0,03$ & $0,41^{\mathrm{a}} \pm 0,06$ \\
Kuning (Ku) & $0,37 \pm 0,05$ & $0,45 \pm 0,03$ & $0,58^{\mathrm{d}} \pm 0,06$ \\
Ketan (Ke) & $0,54 \pm 0,02$ & $0,62 \pm 0,06$ & $0,52^{\mathrm{c}} \pm 0,05$ \\
Boyem (By) & $0,49 \pm 0,06$ & $0,54 \pm 0,04$ & $0,47^{\mathrm{b}} \pm 0,09$ \\
Gatotkaca (Gk) & $0,51 \pm 0,08$ & $0,42 \pm 0,08$ & 0 \\
\hline Rerata (\%db) & $0,50 \pm 0,09$ & $0,49 \pm 0,09$ & \\
\hline
\end{tabular}

Keterangan: sig. varietas $=0,000$, sig. jenis fermentasi $=0,619$, sig. varietas*jenis fermentasi $=0,000, \mathrm{R}$ Squared $=0,720$. Notasi huruf kapital dan huruf kecil yang sama pada kolom dan baris yang sama menunjukkan berbeda tidak nyata pada $\mathrm{a}=0,05$ 
Kadar lemak mocaf dipengaruhi oleh varietas ubi kayu yang digunakan. Menurut (Hastutik, et al, 2017), kadar lemak ubi kayu varietas Gambyong sebesar 0,80\% (db) dan varietas gatotkaca sebesar $0,50 \%$ (db). Selama fermentasi terjadi penurunan kadar lemak diduga karena sebagian lemak digunakan untuk metabolisme mikroba yang berperan dalam fermentasi mocaf. Menurut (Puspadewi et al, 2011), nutrisi yang biasanya digunakan sebagai sumber karbon adalah karbohidrat, lemak, dan protein. Selain itu, penurunan kadar lemak diduga terjadi karena lemak dipecah menjadi asam lemak dan gliserol oleh enzim lipase yang dihasilkan oleh Lactobacillus plantarum selama fermentasi (Behera, dan Ray, 2017).

\section{Karbohidrat}

Varietas ubi kayu berpengaruh nyata (sig. 0,00) terhadap kadar karbohidrat mocaf yang dihasilkan (Tabel 8). Menurut (Sulistyo dan Nakahara, 2015), terjadi penurunan kadar karbohidrat pada fermentasi mocaf. Karbohidrat digunakan sebagai sumber karbon untuk melakukan aktivitas metabolisme mikroba. Kadar karbohidrat mocaf yang dihasilkan dari 5 varietas ubi kayu menunjukkan nilai yang berbeda-beda karena kandungan karbohidrat awal dari varietas tersebut juga berbeda-beda. Perbedaan kadar karbohidrat pada ubi kayu selain dipengaruhi oleh jenis (varietas) juga dipengaruhi oleh umur, tempat tumbuh, perawatan, dan pemupukan selama masa budidayanya (Hastutik, et al, 2017).

Jenis fermentasi tidak memberi pengaruh secara nyata (sig. 0,07) terhadap kadar karbohidrat mocaf. Sedangkan kombinasi antara varietas ubi kayu dan jenis fermentasi yang digunakan dalam pembuatan mocaf berpengaruh nyata terhadap kadar karbohidrat mocaf (sig. 0,00).

Tabel 8. Kadar Karbohidrat Mocaf dari berbagai varietas ubi kayu dan tipe fermentasi

\begin{tabular}{|c|c|c|c|}
\hline \multirow{2}{*}{ Varietas } & \multicolumn{2}{|c|}{ Fermentasi } & \multirow{2}{*}{ Rerata (\%db) } \\
\hline & Spontan(o) & Starmof (s) & \\
\hline Gambyong (Gb) & $90,72 \pm 0,15$ & $91,23 \pm 0,19$ & $90,98^{\mathrm{a}} \pm 0,31$ \\
\hline Kuning (Ku) & $90,67 \pm 0,15$ & $91,31 \pm 0,76$ & $91,49^{b} \pm 0,22$ \\
\hline Ketan (Ke) & $91,47 \pm 0,10$ & $91,70 \pm 0,14$ & $91,58^{b} \pm 0,16$ \\
\hline Boyem (By) & $92,31 \pm 0,15$ & $92,13 \pm 0,10$ & $92,22^{c} \pm 0,15$ \\
\hline Gatotkaca (Gk) & $92,48 \pm 0,34$ & $92,67 \pm 0,26$ & $92,58^{\mathrm{d}} \pm 0,26$ \\
\hline Rerata (\%db) & $91,73 \pm 0,67$ & $91,81 \pm 0,56$ & \\
\hline
\end{tabular}

\section{Karakteristik Mikrobiologi}

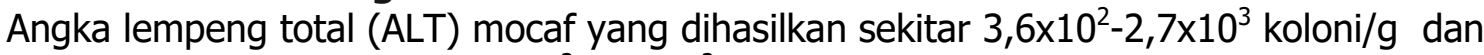
Angka kapang/khamir (AKK) $<2,5 \times 10^{2}-8,6 \times 10^{2}$ koloni/g (Tabel 9). Berdasarkan SNI 76222011 (BSN, 2011) tentang syarat mutu tepung mocaf, batas maksimal nilai ALT $1 \times 10^{6}$ koloni/g dan AKK maksimal $1 \times 10^{4}$ koloni/g. Fermentasi spontan menghasilkan nilai ALT yang lebih tinggi dibandingkan dengan fermentasi menggunakan stater. Fermentasi alami tidak dapat mengendalikan mikrob kontaminasi yang kemungkinan ada. Ojo dan Akande, (2013) juga menyebutkan bahwa fermentasi alami ubi kayu umumnya dilakukan melalui teknik fermentasi padat/solid state fermentation (SSF) yang diakhiri dengan proses penjemuran di bawah sinar matahari dan penyimpanan sebelum dikonsumsi. Proses ini sangat berpotensi terjadinya kontaminasi kapang penghasil mikotoksin, seperti yang terjadi pada proses pembuatan gari. 
Tabel 9. Angka Lempeng Total (ALT) dan Angka Kapang Khamir (AKK) Mocaf dari Berbagai Varietas Ubi kayu dan Tipe Fermentasi

\begin{tabular}{ccc}
\hline Varietas & $\begin{array}{c}\text { ALT } \\
\text { (koloni/g) }\end{array}$ & $\begin{array}{c}\text { AKK } \\
\text { (koloni/g) }\end{array}$ \\
\hline Gbo & $2,6 \times 10^{3}$ & $7,0 \times 10^{2}$ \\
Gbs & $3,6 \times 10^{2}$ & $3,1 \times 10^{2}$ \\
Kuo & $4,2 \times 10^{2}$ & $2,6 \times 10^{2}$ \\
Kus & $4,1 \times 10^{2}$ & $4,3 \times 10^{2}$ \\
Keo & $1,4 \times 10^{3}$ & $7,6 \times 10^{2}$ \\
Kes & $5,3 \times 10^{2}$ & $<2,5 \times 10^{2}$ \\
Byo & $2,2 \times 10^{3}$ & $8,6 \times 10^{2}$ \\
Bys & $2,7 \times 10^{3}$ & $7,5 \times 10^{2}$ \\
Gko & $1,3 \times 10^{3}$ & $<2,5 \times 10^{2}$ \\
Gks & $3,6 \times 10^{2}$ & $4,7 \times 10^{2}$ \\
\hline
\end{tabular}

keterangan: Gbo (Gambyong spontan), Gbs (Gambyong Starmof), Kuo (Kuning spontan), Kus (Kuning Starmof), Keo (Ketan spotan), Kes (Ketan Starmof), Byo (Boyem spontan), Bys (Boyem Starmof), Gko (Gatotkaca spontan), Gks (Gatotkaca Starmof)

Angka Lempeng Total (ALT) digunakan sebagai indikator higine sanitasi proses pembuatan produk, proses pengawasan, dan sebagai dasar kecurigaan dapat atau tidak diterimanya produk untuk dikonsumsi berdasarkan kualitas mikrobiologinya (Puspandari dan Isnawati, 2015).

\section{KESIMPULAN}

Varietas ubi kayu berpengaruh nyata terhadap derajat putih, kadar air, abu, protein, lemak dan karbohidrat. Jenis fermentasi berpengaruh nyata terhadap derajat putih, kadar air, abu, protein dan tidak berpengaruh nyata terhadap lemak dan karbohidrat. Kombinasi antara varietas dan jenis fermentasi berpengaruh nyata terhadap derajat putih, kadar air, abu, protein, lemak dan karbohidrat. Fermentasi dengan penambahan starter kering mengakibatkan suhu gelatinisasi dan viskositas balik mocaf semakin tinggi serta viskositas puncak dan dingin semakin rendah. Angka lempeng total (ALT) dan angka kapang/khamir (AKK) memenuhi syarat mutu dari SNI untuk semua tipe fermentasi.

\section{UCAPAN TERIMA KASIH}

Penulis mengucapkan terima kasih kepada BPTBA LIPI melalui program IPTEKDA (Implementasi Teknologi di Daerah) Tahun 2017, juga kepada Wiwin Widiastuti, Nisa Sepdifa, Sri Endartini, Unit Pelaksanaan Produksi Cassava - Badan Keswadayaan masyarakat (UPP BKM) Rongkop dan Kelompok Wanita Tani (KWT) Semugih, Rongkop, Gunungkidul.

\section{DAFTAR PUSTAKA}

Aini, N. 2013. Teknologi Fermentasi pada Tepung Jagung. Graha Ilmu.

Amanu, F. N., dan Susanto, W. H. 2014. Pembuatan Tepung Mocaf di Madura (Kajian Varietas dan Lokasi Penanaman) Terhadap Mutu dan Rendemen. Jurnal Pangan Dan Agroindustri, 2(3), 161-169.

AOAC. 2000. Official Method of Analysis of The Association of Official Analytical of Chemist. The Associacion of Official Analytical Chemist, Inc., USA.

Badan Ketahanan Pangan dan Penyuluhan DIY. 2016. Data Wilayah dan Potensi Bahan Pangan dan Olahan. 1. 
Badan Pusat Statistik. 2015. Produksi tanaman pangan DIY 2015. https://yogyakarta.bps.go.id/publication/download.html?nrbvfeve=N2U2YjQ3NDhhODc3 ODI5NjY5MzVINTg1\&xzmn=aHR0cHM6Ly95b2d5YWthcnRhLmJwcy5nby5pZC9wdWJsa WNhdGlvbi8yMDE2LzA5LzMwLzdINmIONzQ4YTg3NzgyOTY2OTM1ZTU4NS9wcm9kdWtza S10YW5hbWFuLXBhbmdhbi1kYWVyYWgtaXN0aW1ld

Badan Standarisasi Nasional. 2009. Standar Nasional Indonesia No. SNI 01-3751-2009 tentang Tepung Terigu sebagai Bahan Makanan. Badan Standarisasi Nasional.

Badan Standarisasi Nasional. 2011. Standar Nasional Indonesia No. SNI 7622-2011 tentang Tepung Mocaf.

Behera, S. S., dan Ray, R. C. 2017. Microbial linamarase in cassava fermentation. Microbial Enzyme Technology in Food Applications, 333-346. https://doi.org/10.1201/9781315368405

Brookfield Engineering Laboratories. 2005. Brookfield DV-II+Pro Viscometer Operating Instruction Manual No. M03-165-A0404.

Eleazu, C. O., dan Eleazu, K. C. 2012. Determination of the Proximate Composition, Total Carotenoid, Reducing Sugars and Residual Cyanide Levels of Flours of 6 New Yellow and White Cassava (Manihot esculenta Crantz) Varieties. American Journal of Food Technology, 7(10), 642-649. https://doi.org/10.3923/ajft.2012.642.649

Hadnađev, T.R.D., Dokic, L.P., Hadnadev, M.S., Pojić, M.M., Rakita, S.M., dan Torbica, A. M. 2013. Changes in quality parameters of bread supplemented with OSA starch during storage. Food and Feed Research, 40 (2), 101-108. http://fins.uns.ac.rs/ejournal/uploads/Magazines/magazine_132/Changes_in_quality_parameters_of_bread_s upplemented_with_OSA_starch_during_storage.pdf

Hastutik, Tri, S., Dewi, S.S., dan Setiawan, C. K. 2017. Karakteristik Berbagai Varietas Singkong untuk Pembuatan Mocaf di Gunungkidul.

Hendriadi, A. 2020. Diversifikasi Pangan Lokal Seumber Karbohidrat Non Beras. 5.

Inuhan, B., Arreneuz, S., dan Wibowo, M. A. 2016. Optimasi produksi protein sel tunggal (PST) dari bakteri yang terdapat pada gastrointestinal (GI) ikan nila (Oreochromis niloticus) dan ikan kembung (Scomber canagorta). Jkk, 5(1), 24-28.

Kartikasari, S. N., Sari, P., dan Subagio, A. 2016. Karakterisasi Sifat Kimia, Profil Amilografi (RVA) dan Morfologi Granula (SEM) Pati Singkong Termodifikasi secara Biologi. Jurnal Agroteknologi, 10

(01),

$12-24$. https://jurnal.unej.ac.id/index.php/JAGT/article/view/4472/3327

Kementerian Perdagangan RI. 2016. Ekspor Tepung Olahan Semanis Madu. Warta Ekspor, $1-20$.

Khasanah, Y. dan Helmi, R. 2020. Pentingnya Mengembangkan Mocaf (Catatan Pengantar) (Rahmi Lestari Helmi (ed.); 1st ed., p. 207). https://lipipress.lipi.go.id/detailpost/modified-cassava-flour-mocaf-optimalisasi-prosesdan-potensi-pengembangan-industri-berbasis-umkm

Kurniadi, M., Nurhayati, R., Damayanti, E., dan Widiastuti, W. 2014. Teknologi Pembuatan Mocaf dan Olahannya. BPTBA LIPI.

Moral, U., Nagar, P., Maan, S., dan Kaur, K. 2017. A Growth of Different Types of Microorganism, Intrinsic and Extrinsic Factors of Microorganism and their Affects in Food: A Review. International Journal of Current Microbiology and Applied Sciences, 6 (1), 290-298. https://doi.org/10.20546/ijcmas.2017.601.035

Ojo, A, dan Akande, E. 2013. Quality evaluation of gari produced from cassava and sweet potato tuber mixes. African Journal of Biotechnology, 12(31), 4920-4924. https://doi.org/10.5897/ajb12.2504

Puspadewi, R., Adirestuti, P., dan Anggraeni, G. 2011. Aktivitas Metabolit Bakteri Lactobacillus plantarum dan Perannya dalam Menjaga Kesehatan Saluran Pencernaan. 
Konferensi Nasional Sains Dasar Dan Aplikasinya, June 2011, 1-11.

Puspandari, N., dan Isnawati, P. 2015. Deskripsi Hasil Uji Angka Lempeng Total (ALT) Pada Beberapa Susu Formula Bayi Formula. Artikel Riset, Jurnal Kefarmasian Indonesia, 5 (2), 106-113. https://media.neliti.com/media/publications/105149-ID-deskripsi-hasil-ujiangka-lempeng-total.pdf

Putri, N. A. 2015. SIfat rheologi mocaf (Modified Cassava Flour) dan tapioka dengan variasi pH. https://repository.unej.ac.id/handle/123456789/65349

Putri, N. A., Herlina, H., dan Subagio, A. 2018. Karakterisasi mocaf (Modified Cassava Flour) berdasarkan metode penggilingan dan lama fermentasi. Jurnal Agroteknologi, 12(01), 79. https://doi.org/10.19184/j-agt.v12i1.8252

Rosyadi, Ihsan, M., Toekidjo., dan Supriyanta. 2014. Karakterisasi Ubi Kayu Lokal (Manihot utilissima L.) Gunungkidul. Vegetalika, 3 (2), 59-71. https://doi.org/https://doi.org/10.22146/veg.5152

Sagala, E., dan Suwarto. 2017. Manajemen Panen dan Pasca Panen Ubi Kayu (Manihot esculenta Crantz) untuk Bahan Baku Industri Tapioka di Lampung. Buletin Agrohorti, 5(3), 400-409. https://doi.org/10.29244/agrob.v5i3.16486

Sarjiyah., Hariyono., dan Supangkat, G. 2016. Identifikasi Singkong Varietas Lokal Kabupaten Gunung Kidul Daerah Istimewa Yogyakarta. Laporan Penelitian unggul prodi. Program studi Agroteknologi Fakultas Pertanian Universitas Muhammadiyah Yogyakarta, Yogyakarta.

Seveline. 2018. Pembuatan tepung mocaf dengan penggunaan bakteri asam laktat dan lamanya perendaman. Laporan penelitian Program Studi Teknologi Pangan Fakultas Bioindustri Universitas Trilogi.

Subagio, A. 2013. Kajian Strategi Pengembangan Pasar untuk Meningkatkan Permintaan Tepung Mocaf (Modified Cassava Flour).

Sulistyo, J., dan Nakahara, K. 2015. Cassava Flour Modification by Microorganism. Japan International Research Center for Agricultural Sciences, NOVEMBER 2013. https://doi.org/10.13140/2.1.3702.4966

Tefera, T., Ameha, K., dan Biruhtesfa, A. 2014. Cassava based foods: Microbial fermentation by single starter culture towards cyanide reduction, protein enhancement and palatability. International Food Research Journal, 21 (5), 1751-1756.

Winarno, F. 2008. Kimia Pangan dan Gizi. M-Brio Press.

Wulandari, F., Nazaruddin, dan Amaro, M. 2021. Pengaruh Jenis Bakteri Asam Laktat Dan Lama Fermentasi Terhadap Mutu Fisik, Kimia, Organoleptik Dan Mikrobiologi Tepung Mocaf. Prosiding SAINTEK | e-ISSN: 2774-8057. Lembaga Penelitian dan Pengabdian Kepada Masyarakat Universitas Mataram 3(November 2020), 9-10.

Yulifianti, R., dan Ginting, E. 2011. Karakteristik Tepung Mocaf Dari Beberapa Varietas/Klon Ubikayu. Prosiding Seminar Hasil Penelitian Tanaman Aneka Kacang Dan Umbi., September 2010, 621-629. 